\title{
Analysis of thermal and water management with temperature-dependent diffusion effects in membrane of proton exchange membrane fuel cells
}

\author{
Wei-Mon Yan ${ }^{\mathrm{a}, *}$, Falin Chen ${ }^{\mathrm{b}}$, Hung-Yi Wu ${ }^{\mathrm{b}}$, Chyi-Yeou Soong ${ }^{\mathrm{c}}$, Hsin-Shen Chu ${ }^{\mathrm{d}}$ \\ a Department of Mechatronic Engineering, Huafan University, Shih Ting, Taipei 223, Taiwan, ROC \\ ${ }^{\mathrm{b}}$ Institute of Applied Mechanics, National Taiwan University, Taipei 106, Taiwan, ROC \\ ${ }^{c}$ Department of Aerospace and System Engineering, Feng Chia University, Seatwen, Taichung 407, Taiwan, ROC \\ ${ }^{d}$ Department of Mechanical Engineering, Chiao Tung University, Hsin-Chu 300, Taiwan, ROC
}

Received 12 August 2003; accepted 21 November 2003

\begin{abstract}
In the present work, the detailed thermal and water management in the membrane of proton exchange membrane fuel cells (PEMFC) is investigated numerically. The coupling effects of mass diffusion and temperature gradient on the water distribution in the membrane are taken into account with consideration of the temperature-dependent diffusivity. Thermal and water transport equations with various boundary conditions are solved by the control volume finite difference method. Predictions show that under the conditions of fixed water concentration at the cathode side, the effect of cathode temperature, $T_{\mathrm{c}}$, on the water concentration is significant. Increases in $T_{\mathrm{c}}$ may lead to an increase in membrane dehydration. At the water-flux condition on the cathode side, the influence of the operating temperature on the water distribution in the membrane shows a similar trend. The effects of the anode temperature, $T_{\mathrm{a}}$, on the water management in the membrane are also examined. It is found that $T_{\mathrm{a}}$ has considerable impact on the water content in the membrane. In addition, high current density may cause non-uniformity of the temperature distribution in the membrane.
\end{abstract}

(C) 2003 Elsevier B.V. All rights reserved.

Keywords: Diffusion effects; Proton exchange membrane fuel cells; Thermal and water management

\section{Introduction}

Recent interests in proton exchange membrane fuel cell (PEMFC) systems have caused extensive studies on thermal and water management. During (PEMFC) operation, water molecules can be carried from the anode side to the cathode side of the membrane by electro-osmosis, and if the transport rate of water is higher than the back-diffusion rate from the anode to the cathode, the membrane will become dehydrated and too resistive to conduct high current. At the cathode side of the membrane, where water molecules are not only transported from anode side but also generated by the cathodic reaction, electrode flooding occurs when the water removal rate fails to keep up with its transport rate out of the electrode. On the other hand, the temperature gradient in the membrane may influence the fuel-cell performance by affecting the transport of water and gaseous species as well as the electrochemical reactions in the electrode. Therefore,

\footnotetext{
* Corresponding author. Tel.: +886-2-2663-3847; fax: +886-2-2663-3847.

E-mail address: wmyan@huafan.hfu.edu.tw (W.-M. Yan).
}

it is appealing to have a theoretical model which can provide detailed understanding of the governing phenomena inside the membrane. This motivates the present study, which examines the water concentration and temperature within membrane of PEMFCs.

In past decades, there have been numerous studies of transport phenomena in PEMFCs. Bernardi [1] proposed a one-dimensional model of water management with consideration of the membrane thickness. By using this model, it was found that the diffusion in the water production and evaporation rate in the PEMFC can result in the flooding of the electrode or the membrane dehydration, and therefore affect the performance of the fuel cells. In addition, the effects of the humidification on the current-voltage curves of the fuel cells under various operating conditions were presented. Springer et al. [2] developed an isothermal, one-dimensional, steady-state model for the PEMFC with Nafion ${ }^{\circledR} 117$ [2]. Diffusion, electro-osmotic drag and membrane conduction were all taken into account. The results showed that the net water-flux ratio under a typical operating condition is much less than that within a fully-hydrated membrane. It was also found that the membrane resis- 


\begin{tabular}{|c|c|}
\hline \multicolumn{2}{|c|}{ Nomenclature } \\
\hline$C_{\mathrm{a}}$ & $\begin{array}{l}\text { water concentration per unit volume at } \\
\text { the anode side }\left(\mathrm{mol} \mathrm{cm}^{-3}\right)\end{array}$ \\
\hline$C_{\mathrm{c}}$ & $\begin{array}{l}\text { water concentration per unit volume at } \\
\text { the cathode side }\left(\mathrm{mol} \mathrm{cm}^{-3}\right)\end{array}$ \\
\hline$C_{\mathrm{H}_{2} \mathrm{O}}$ & $\begin{array}{l}\text { water concentration in the membrane per } \\
\text { unit volume }\left(\mathrm{mol} \mathrm{cm}^{-3}\right)\end{array}$ \\
\hline$C_{p, 1}$ & specific heat of liquid water $\left(\mathrm{J} \mathrm{kg}^{-1} \mathrm{~K}^{-1}\right)$ \\
\hline$d$ & density of the membrane $\left(\mathrm{g} \mathrm{cm}^{-3}\right)$ \\
\hline$D$ & $\begin{array}{l}\text { diffusion coefficient of water in the } \\
\text { membrane }\left(\mathrm{cm}^{2} \mathrm{~s}^{-1}\right)\end{array}$ \\
\hline$D_{\mathrm{a}}$ & $\begin{array}{l}\text { diffusion coefficient of water at the } \\
\text { anode side }\left(\mathrm{cm}^{2} \mathrm{~s}^{-1}\right)\end{array}$ \\
\hline$D_{\mathrm{c}}$ & $\begin{array}{l}\text { diffusion coefficient of water at the } \\
\text { cathode side }\left(\mathrm{cm}^{2} \mathrm{~s}^{-1}\right)\end{array}$ \\
\hline$F$ & Faraday's constant $96487\left(\mathrm{C} \mathrm{mol}^{-1}\right)$ \\
\hline$i$ & operating current density $\left(\mathrm{A} \mathrm{cm}^{-2}\right)$ \\
\hline$K$ & thermal conductivity $\left(\mathrm{W} \mathrm{cm}{ }^{-1} \mathrm{~K}^{-1}\right)$ \\
\hline$\dot{m}_{\mathrm{H}_{2} \mathrm{O}}$ & molecular flux of water $\left(\mathrm{mol} \mathrm{cm}^{-1} \mathrm{~s}^{-1}\right)$ \\
\hline & molecular weight of water $\left(\mathrm{kg} \mathrm{mol}^{-1}\right)$ \\
\hline$R$ & ohmic resistance per unit volume $\left(\Omega \mathrm{cm}^{-1}\right)$ \\
\hline$T$ & temperature $\left({ }^{\circ} \mathrm{C}\right)$ \\
\hline V & volume of the membrane $\left(\mathrm{cm}^{3}\right)$ \\
\hline$w$ & water transfer coefficient \\
\hline \multicolumn{2}{|c|}{ Greek letters } \\
\hline$\kappa$ & $\begin{array}{l}\text { flux of water into membrane by } \\
\text { concentration gradient }\left(\mathrm{m} \mathrm{s}^{-1}\right)\end{array}$ \\
\hline$\lambda$ & $\begin{array}{l}\text { membrane hydration or water content } \\
\text { (moles water/moles charge sites) }\end{array}$ \\
\hline$v$ & $\begin{array}{l}\text { rate of water entry the membrane } \\
\text { proportional to the current density }\end{array}$ \\
\hline \multicolumn{2}{|c|}{ Subscripts } \\
\hline a & anode side of the membrane \\
\hline & cathode side of the membrane \\
\hline $\mathrm{m}$ & membrane \\
\hline
\end{tabular}

tance is significantly enhanced as the current density is increased. By comparison, the resistance is reduced for a thin membrane.

Fuller and Newman [3] examined experimentally the water transport number in Nafion ${ }^{\circledR} 117$. The relationship between transport number and electro-osmotic coefficient was presented. It was demonstrated that the transport number decreases slowly as the membrane is dehydrated, but falls quickly to zero when the water concentration approaches to zero. Nguyen and White [4] performed modelling of the water and heat management in PEMFC. The model included the effect of electro-osmosis, diffusion of water; heat transfer from solid phase to gas phase and latent heat as water evaporation and condensation. It was found that the ohmic loss is noticeable at high current density. The voltage loss is twice amount of that at the cathode electrode. The reactant gas at the anode needs to be humidified since the membrane is dehydrated at high current densities. Fuller and Newman [5] proposed a two-dimensional mathematical model for the water and thermal management and the utilization of the fuel of a PEMFC. Due to the water sorption depending strongly on the temperature, the waste heat is a critical parameter in the design of the proton exchange membrane fuel cells.

In the numerical analysis of Mosdale and Srinivasan [6], it was clearly seen that the large current density limit of fuel cell is more for pure oxygen than for air used at the cathode side. Voss et al. [7] proposed a new technique for water management, by which it was found that if the back-diffusion rate and the water concentration are increased, the water at the cathode could be removed via the anode stream. Xie and Okada [8] showed that the water transfer coefficient of Nafion ${ }^{\circledR} 117$ membrane in the $\mathrm{H}^{+}$form was 2.6. The Nafion ${ }^{\circledR} 117$ membrane has good performance for $\mathrm{HCl}$ solutions with a concentration that ranges from 0.003 to $1 \mathrm{~N}$. Additionally, it was also shown that the water transport behaviour is related to the surface-change density, the hydration enthalpy and the water content in the membrane.

By using a linear transport equation for water in the PEMFC, detailed transport phenomena of the PEMFC, including diffusion and electro-osmotic drag effects, were analytically solved by Okada et al. [9,10]. In these studies, both semi-finite and finite boundaries were considered. The predicted results showed that the current density, the water penetration parameters, the membrane thickness and the diffusion coefficient of water are the key factors in determination of the water content in the membrane. Foreign impurities such as $\mathrm{NaCl}$ will cause a serious impact on the water depletion at the anode side. Water supplied from the anode side of the membrane is needed. Okada extended the modelling to account of the effect of impurity ions at both the anode and the cathode side of the membrane $[11,12]$. The results indicated that both the current density and the membrane thickness are important parameters in the water management of the membrane, especially when the membrane surface has impurity ions. The distribution of contaminant ions degrades the membrane and the performance of the fuel cell. Deterioration of cell performance in the presence of non-uniform impurities in the membrane is more serious than in the case of non-uniform impurities distribution.

Thermal management in the direct methanol fuel cell (DMFC) was investigated by Argyropoulos et al. [13,14]. A model was developed to investigate the effects of various operating parameters (feed and oxidant temperatures, flow rate and pressure, operating current density) and system design (active area, material properties and geometry) on the performance of the DMFC. The mathematical model includes the gas-diffusion layer, the catalyst layer and the membrane. It can also be used to predict the steady-state performance of the DMFC stacks. The diffusion flux across a Nafion ${ }^{\circledR}$ membrane can be accurately predicted by using Fick's diffusion coefficient. Motupally et al. [15] showed that increasing the 
cell pressure will decrease the water activity and reduce the diffusion coefficient.

Baschuk and Li [16] developed a mathematical model with variable degrees of water flooding in the PEMFC. Physical and electrochemical processes occurring in the membrane electrolyte, the cathode catalyst layer, the electrode backing layer and the flow channel were considered. Compared with experimental results, it was found that when air is used as the cathode fuel, the flooding phenomena are similar for different operating conditions of the pressures and temperatures. When the cell pressure is increased significantly, the water flooding in the electrode becomes serious. This will significantly reduce the power output. Recently, Rowe and $\mathrm{Li}$ [17] carried out a two-dimensional simulation of water transport in the PEMFC without external humidification. This model calculated the fraction of product water leaving the anode side of the fuel cell. The results indicated that the amount of water leaving the anode depends on the hydrogen stoichiometry, oxygen stoichiometry, current density, and cell temperature. One of the most recent PEMFC models was proposed by Djilali and Lu [18] for analysis of fuel-cell performance and water transport. The thermodynamic equation was determined by the Nernst equation and the reaction kinetics were calculated by the Butler-Volmer equation. Analysis showed that the water requirement to prevent the membrane from dehydrating or flooding is important.

From the literature reviews presented above, it is concluded that the effects of the temperature gradient on water management in the PEMFCs are not well defined. In fact, the water content in the membrane can be influenced by the local temperature distribution since the diffusivity in water transport is temperature-dependent. On the other hand, the energy balance is also closely related to the water content or local water concentration in the membrane. The objective of the present study is to explore the coupling mechanisms of thermal-mass-transport phenomena in the membrane of PEMFC systems.

\section{Analysis}

Consideration is given to a PEMFC in which the polymer electrolyte membrane made from Nafion ${ }^{\circledR}$. Its thickness is smaller than its length and width, as shown schematically in Fig. 1. Therefore, it can treat it as a one-dimensional problem. To simplify the analysis, the following assumptions are made.

(i) The transports are steady-state and one-dimensional.

(ii) The pressure is constant.

(iii) An ideal gas mixture is assumed.

(iv) Liquid water flux is only determined in the membrane.

(v) The volume of the membrane is constant.

(vi) The convective effects are negligible for a small Reynolds number.

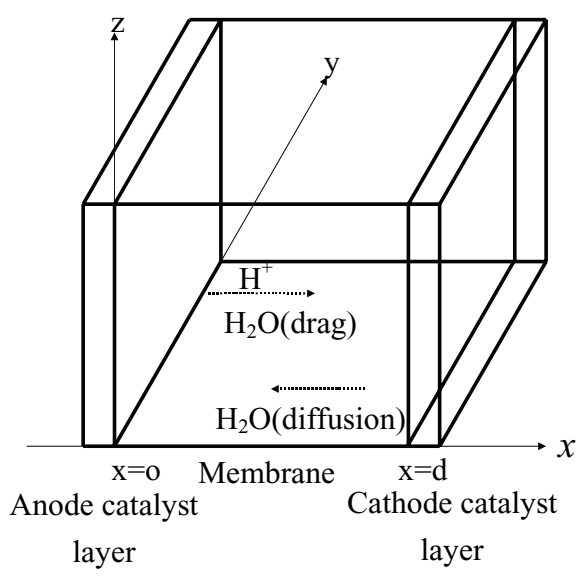

Fig. 1. Schematic diagram of physical system.

(vii) Heat loss to the surrounding environment is small and can be neglected.

(viii) Joule-heating is considered to be to the membrane ohmic resistance.

With the above assumptions, the governing equations for the water balance can then be formulated as follows.

\subsection{Water transfer equation}

In the membrane of a PEMFC, the water flux is composed of two components, namely, a diffusion flux and an electro-osmosis flux $[4,5]$. The latter is proportional to the current density, $i$. The total water flux can then be described by:

$\dot{m}_{\mathrm{H}_{2} \mathrm{O}}=\left(-D_{\mathrm{H}_{2} \mathrm{O}} \frac{\mathrm{d} C_{\mathrm{H}_{2} \mathrm{O}}}{\mathrm{d} x}+\frac{i}{F} w_{\mathrm{H}_{2} \mathrm{O}}\right)$,

where: $\dot{m}_{\mathrm{H}_{2} \mathrm{O}}$ is the molar flux of the water; $D_{\mathrm{H}_{2} \mathrm{O}}$ is the diffusion coefficient of water in the membrane; $C_{\mathrm{H}_{2} \mathrm{O}}$ is the water concentration in the membrane; $i$ is the current density; $F$ is the Faraday constant; $w_{\mathrm{H}_{2} \mathrm{O}}$ is the water transfer coefficient. Therefore, the rate of water concentration is given by:

$\frac{\partial C_{\mathrm{H}_{2} \mathrm{O}}}{\partial t}=-\frac{\partial \dot{m}_{\mathrm{H}_{2} \mathrm{O}}}{\partial x}=\frac{\partial}{\partial x}\left(D_{\mathrm{H}_{2} \mathrm{O}} \frac{\partial C_{\mathrm{H}_{2} \mathrm{O}}}{\partial x}-\frac{i}{F} w_{\mathrm{H}_{2} \mathrm{O}}\right)$

For steady-state conditions, the above equation becomes:

$\frac{\mathrm{d}}{\mathrm{d} x}\left(D_{\mathrm{H}_{2} \mathrm{O}} \frac{\mathrm{d} C_{\mathrm{H}_{2} \mathrm{O}}}{\mathrm{d} x}-\frac{i}{F} w_{\mathrm{H}_{2} \mathrm{O}}\right)=0$

$\frac{\mathrm{d} D_{\mathrm{H}_{2} \mathrm{O}}}{\mathrm{d} x} \frac{\mathrm{d} C_{\mathrm{H}_{2} \mathrm{O}}}{\mathrm{d} x}+D_{\mathrm{H}_{2} \mathrm{O}} \frac{\mathrm{d}^{2} C_{\mathrm{H}_{2} \mathrm{O}}}{\mathrm{d} x^{2}}-\frac{i}{F} w_{\mathrm{H}_{2} \mathrm{O}}=0$

Generally, the water transfer coefficient is a function of water concentration, for example:

$w_{\mathrm{H}_{2} \mathrm{O}}=w_{1}^{(0)}+w_{1}^{(1)} C_{\mathrm{H}_{2} \mathrm{O}}+w_{1}^{2} C_{\mathrm{H}_{2} \mathrm{O}}^{2}+\cdots$

To simplify the analysis, only the first two terms, $w_{1}^{(0)}$ and $w_{1}^{(1)}$, are taken to represent the zero-order and first-order 
coefficients with respect to $C_{\mathrm{H}_{2} \mathrm{O}}$. The water transfer coefficient can then be expressed as:

$w_{\mathrm{H}_{2} \mathrm{O}}=w_{1}^{(0)}+w_{1}^{(1)} C_{\mathrm{H}_{2} \mathrm{O}}$

The water transfer coefficient for Nafion ${ }^{\circledR}$ membrane is calculated by the following equation $[3,9]$ :

$w_{\mathrm{H}_{2} \mathrm{O}}=\frac{1100 w_{\mathrm{m}} V_{\text {wet }}}{22 d V_{\text {dry }}}$

where: the volume ratio for dry to wet, $V_{\text {wet }} / V_{\text {dry }}$, is 16.2 , and the density of the membrane, $d$, is $2.02 \mathrm{~g} \mathrm{~cm}^{-3}$. In addition, the water transfer coefficient $w_{\mathrm{m}}$ is 3.2 at $80^{\circ} \mathrm{C}$.

The diffusion coefficient for liquid water in the membrane is determined as a function of temperature (in $\mathrm{K}$ ) and membrane hydration [2], i.e.,

$$
\begin{aligned}
D_{\mathrm{H}_{2} \mathrm{O}}= & \exp \left[2416\left(\frac{1}{303}-\frac{1}{T}\right)\right](2.563-0.33 \lambda \\
& \left.+0.0264 \lambda^{2}-0.000671 \lambda^{3}\right) \times 10^{-10}
\end{aligned}
$$

If the membrane hydration parameter $\lambda$ is taken to be 14 , as given in [17], then the above equation reduces to:

$D_{\mathrm{H}_{2} \mathrm{O}}=G \exp \left(\frac{-\xi}{T}\right)$

Here:

$\xi=2416$

$G=2.903 \times 10^{-7} f(\lambda)$

$f(\lambda)=2.563-0.33 \lambda+0.0264 \lambda^{2}-0.000671 \lambda^{3}$

\subsection{Energy equation}

The energy equation is based on Fourier's law of heat conduction; i.e.,

$K_{\mathrm{m}} \frac{\mathrm{d}^{2} T}{\mathrm{~d} x^{2}}+\frac{\mathrm{d}}{\mathrm{d} x}\left(\dot{m}_{\mathrm{H}_{2} \mathrm{O}} C_{p, 1} T\right)+i^{2} R=0$

where: $K_{\mathrm{m}}$ is the membrane thermal conductivity, $C_{p, 1}$ is the specific heat of liquid water, and $R$ is the ohmic resistance per unit volume. The first term represents the diffusion term of the heat, the second term expresses the energy flux due to the convection, and the third term stands for the joule-heating owing to the membrane ohmic resistance.

\subsection{Combination of water transport and energy equations}

At first, the molar flux of water is changed into the mass flux of water. Then Eq. (1) becomes:

$\dot{m}_{\mathrm{H}_{2} \mathrm{O}}=\left(-D_{\mathrm{H}_{2} \mathrm{O}} \frac{\mathrm{d} C_{\mathrm{H}_{2} \mathrm{O}}}{\mathrm{d} x}+\frac{i}{F} w_{\mathrm{H}_{2} \mathrm{O}}\right) M$

where $M$ is the molecular weight of water. Substituting the above equation into Eq. (9) gives:

$$
\begin{gathered}
K_{\mathrm{m}} \frac{\mathrm{d}^{2} T}{\mathrm{~d} x^{2}}+\left[-2 D_{\mathrm{H}_{2} \mathrm{O}} \frac{\mathrm{d} C_{\mathrm{H}_{2} \mathrm{O}}}{\mathrm{d} x} M C_{p, 1}+\frac{2 i}{F} w_{1}^{(1)} C_{\mathrm{H}_{2} \mathrm{O}} M C_{p, 1}\right] \\
\times \frac{\mathrm{d} T}{\mathrm{~d} x}+i^{2} R+\left[-\frac{\mathrm{d} D_{\mathrm{H}_{2} \mathrm{O}}}{\mathrm{d} x} \frac{\mathrm{d} C_{\mathrm{H}_{2} \mathrm{O}}}{\mathrm{d} x} M C_{p, 1}\right. \\
\left.-D_{\mathrm{H}_{2} \mathrm{O}} \frac{\mathrm{d}^{2} C_{\mathrm{H}_{2} \mathrm{O}}}{\mathrm{d} x^{2}} M C_{p, 1}+\frac{i}{F} w_{1}^{(1)} \frac{\mathrm{d} C_{\mathrm{H}_{2} \mathrm{O}}}{\mathrm{d} x} M C_{p, 1}\right] T=0
\end{gathered}
$$

By combining Eqs. (8) and (11), the above equation can be simply expressed as:

$\frac{\mathrm{d}^{2} T}{\mathrm{~d} x^{2}}+\left[A \exp \left(\frac{-\xi}{T}\right) \frac{\mathrm{d} C_{\mathrm{H}_{2} \mathrm{O}}}{\mathrm{d} x}+2 B C_{\mathrm{H}_{2} \mathrm{O}}\right] \frac{\mathrm{d} T}{\mathrm{~d} x}=H$

Here the constant, $A, B$, and $H$ are:

$A=\frac{-2 G M C_{p, 1}}{K_{\mathrm{m}}}$

$B=\frac{i w_{1}^{(1)} M C_{p, 1}}{F K_{\mathrm{m}}}$

$H=\frac{-i^{2} R}{K_{\mathrm{m}}}$

Similarly, the water transfer equation, Eq. (4), can be simplified as:

$\frac{\mathrm{d}^{2} C_{\mathrm{H}_{2} \mathrm{O}}}{\mathrm{d} x}+\left[\frac{\xi}{T^{2}} \frac{\mathrm{d} T}{\mathrm{~d} x}-N \exp \left(\frac{\xi}{T}\right)\right] \frac{\mathrm{d} C_{\mathrm{H}_{2} \mathrm{O}}}{\mathrm{d} x}=0$

where:

$N=\frac{i w_{1}^{(1)}}{F G}$

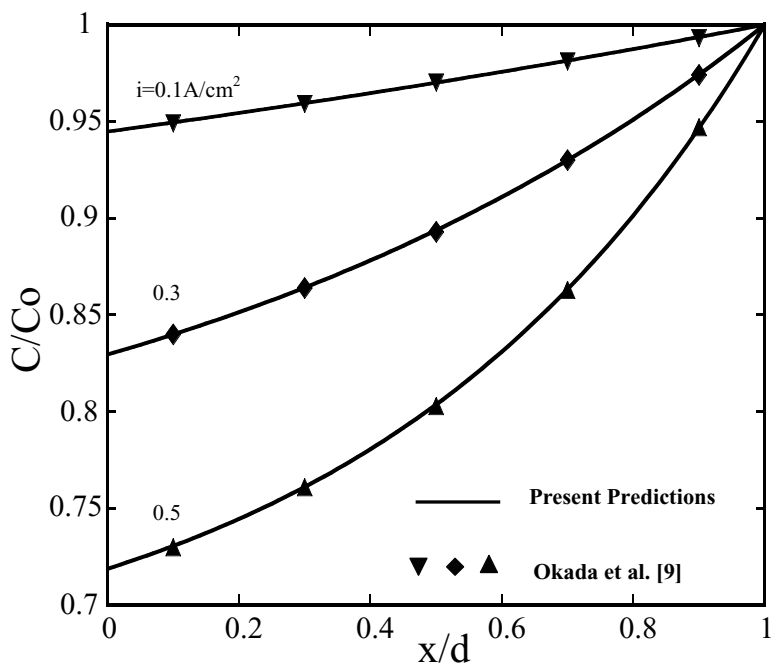

Fig. 2. Comparison of present predictions with those of Okada et al. [15] under conditions of $i=0.1 \mathrm{~A} \mathrm{~m}^{-2}, T_{\mathrm{a}}=60^{\circ} \mathrm{C}, T_{\mathrm{c}}=60^{\circ} \mathrm{C}$ and constant cathode concentration $C_{\mathrm{c}}=1.59 \times 10^{-4} \mathrm{~mol} \mathrm{~m}^{-3}$. 
Table 1

Physical parameters and corresponding values used in this work

\begin{tabular}{|c|c|c|}
\hline Parameter & Symbol & Value \\
\hline Constant term of water transference coefficient at anode side of membrane as expressed by a series expansion of $C_{\mathrm{H}_{2} \mathrm{O}}$ & $w_{\mathrm{a}}^{(0)}$ & 0 \\
\hline Constant term of water transference coefficient at cathode side of membrane as expressed by a series expansion of $C_{\mathrm{H}_{2} \mathrm{O}}$ & $w_{\mathrm{c}}^{(0)}$ & 0 \\
\hline First order term of water transfer coefficient at anode side of membrane as expressed by a series expansion $C_{\mathrm{H}_{2} \mathrm{O}}$ & $w_{\mathrm{a}}^{(1)}$ & $1.28 \times 10^{-4}$ \\
\hline First order term of water transfer coefficient at cathode side of membrane as expressed by a series expansion $C_{\mathrm{H}_{2} \mathrm{O}}$ & $w_{\mathrm{c}}^{(1)}$ & $1.28 \times 10^{-4}$ \\
\hline Current density $\left(\mathrm{A} \mathrm{cm}^{-2}\right)$ & $i$ & $0-3.1$ \\
\hline Coefficient characterizing water flux into anode side of membrane & $v_{\mathrm{a}}$ & $0-1.0$ \\
\hline Coefficient characterizing water flux into cathode side of membrane & $v_{\mathrm{c}}$ & $0-1.0$ \\
\hline Specific conductivity at anode side of membrane $\left(\mathrm{cm} \mathrm{s}^{-1}\right)$ & $\kappa_{\mathrm{a}}$ & $1 \times 10^{-3}$ to 1 \\
\hline Specific conductivity at cathode side of membrane $\left(\mathrm{cm} \mathrm{s}^{-1}\right)$ & $\kappa_{\mathrm{c}}$ & $1 \times 10^{-3}$ to 1 \\
\hline Thickness of membrane $(\mathrm{cm})$ & $d$ & $1 \times 10^{-2}$ \\
\hline Thermal conductivity of membrane $\left(\mathrm{W} \mathrm{cm}^{-1} \mathrm{~K}^{-1}\right)$ & $K_{\mathrm{m}}$ & 0.0014 \\
\hline Specific heat of liquid water $\left(\mathrm{J} \mathrm{kg}^{-1} \mathrm{~K}^{-1}\right)$ & $C_{p, 1}$ & 4180 \\
\hline Faraday constant $\left(\mathrm{A} \mathrm{s} \mathrm{mol}^{-1}\right)$ & $F$ & 96487 \\
\hline Molecular weight $\left(\mathrm{kg} \mathrm{mol}^{-1}\right)$ & $M$ & 0.018 \\
\hline Ohmic resistance per unit length $\left(\Omega \mathrm{cm}^{-1}\right)$ & $R$ & 0.000945 \\
\hline
\end{tabular}
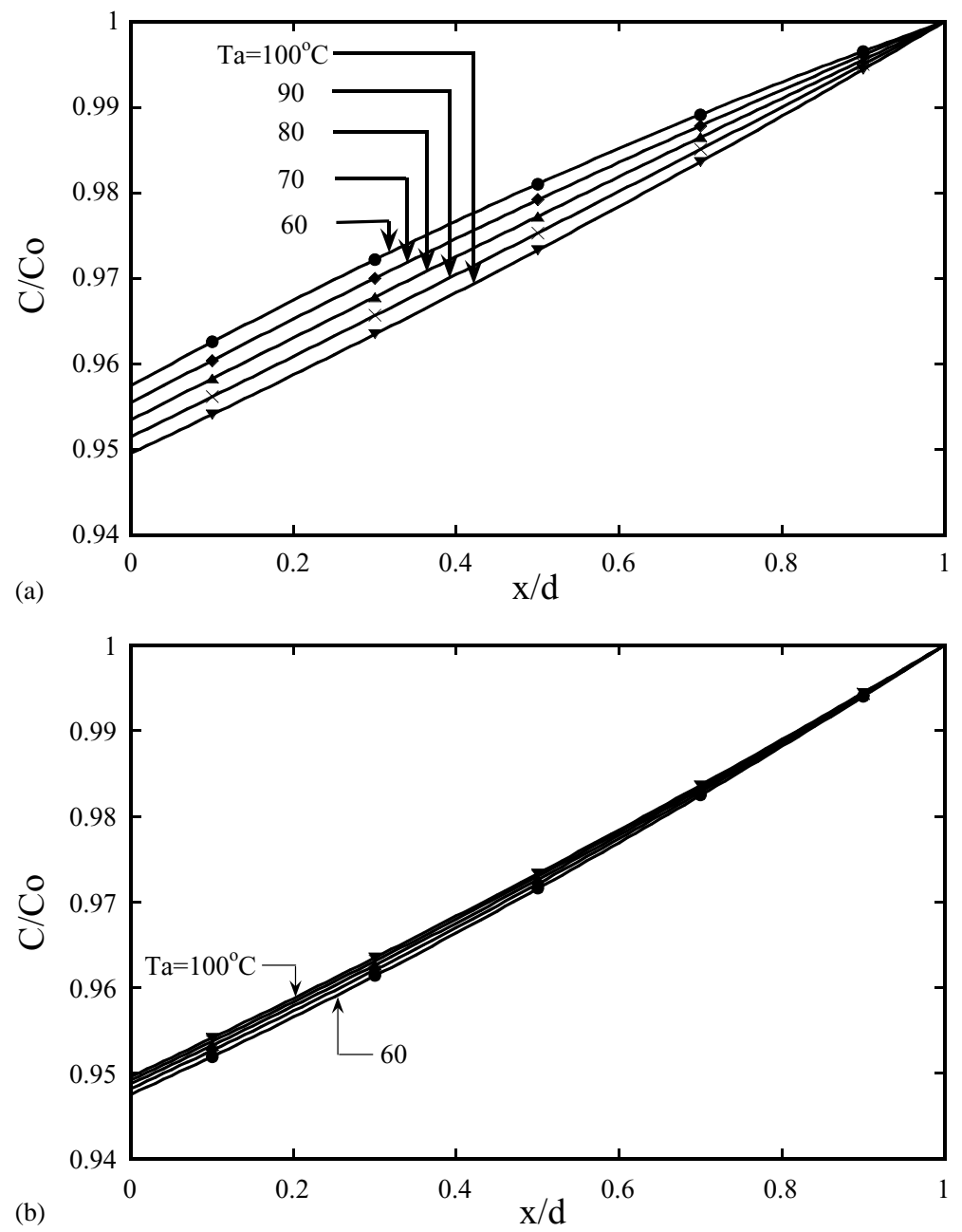

Fig. 3. Water concentration distribution in membrane with $i=0.1 \mathrm{~A} \mathrm{~cm}^{-2}, T_{\mathrm{c}}=100^{\circ} \mathrm{C}$, and constant cathode concentration $C_{\mathrm{c}}=1.59 \times 10^{-4} \mathrm{~mol} \mathrm{~cm}^{-3}$ : (a) constant diffusion coefficient; (b) variable diffusion coefficient. 


\subsection{Boundary conditions}

To solve the governing equations formulated in the last section, the following boundary conditions are specified.

\subsubsection{Concentration conditions at anode-membrane interface}

At the anode-side membrane interface, the condition of water-flux balance [9-12] is imposed, namely:

$$
\begin{aligned}
\frac{v_{\mathrm{a}} i}{F} & +\kappa_{\mathrm{a}}\left[C_{\mathrm{a}}-C_{\mathrm{H}_{2} \mathrm{O}}(0)\right] \\
& =-D_{\mathrm{a}}^{(0)} \frac{\partial C_{\mathrm{H}_{2} \mathrm{O}}(0)}{\partial x}+\frac{i}{F}\left[w_{\mathrm{a}}^{(0)}+w_{\mathrm{a}}^{(1)} C_{\mathrm{H}_{2} \mathrm{O}}(0)\right]
\end{aligned}
$$
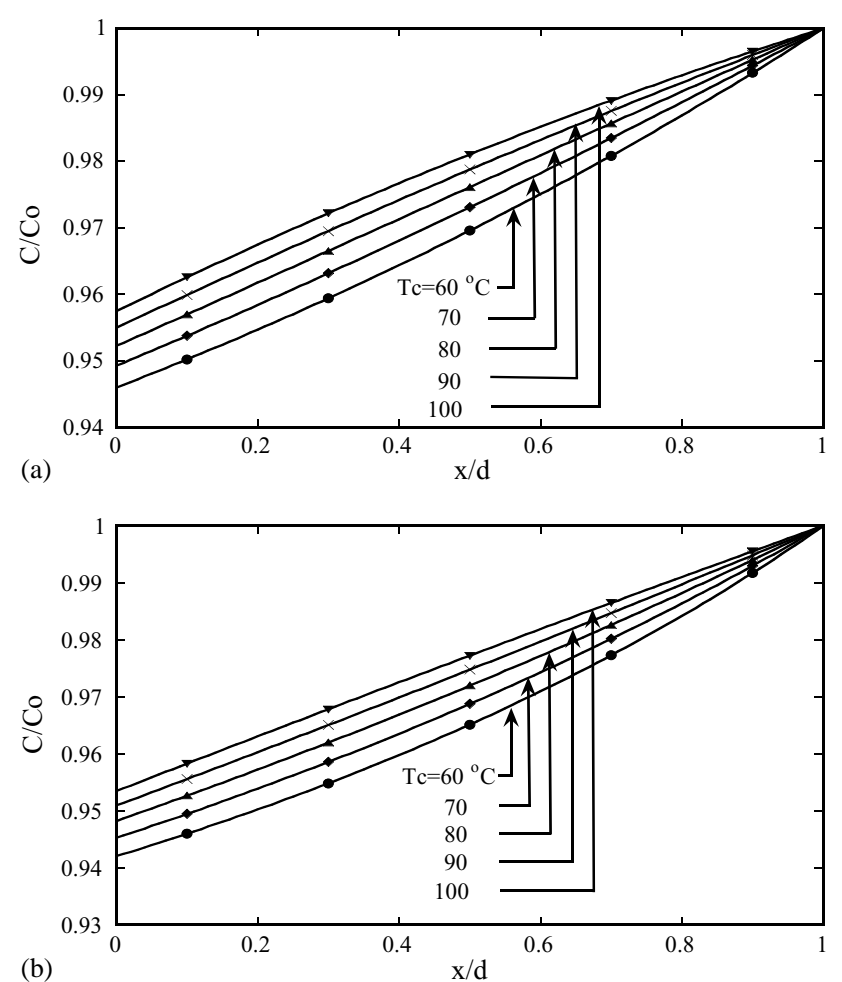

(b)

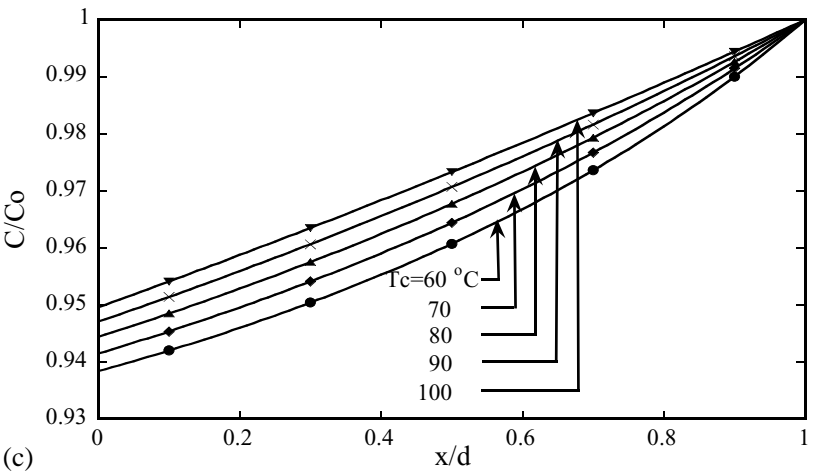

(c)

Fig. 4. Effect of $T_{\mathrm{c}}$ on water concentration distribution with $i=0.1 \mathrm{~A} \mathrm{~cm}^{-2}$ and constant cathode concentration $C_{\mathrm{c}}=1.59 \times 10^{4}$ $\mathrm{mol} \mathrm{cm}{ }^{-3}$ : (a) $T_{\mathrm{a}}=60^{\circ} \mathrm{C}$; (b) $T_{\mathrm{a}}=80^{\circ} \mathrm{C}$; (c) $T_{\mathrm{a}}=100^{\circ} \mathrm{C}$. where: $v_{\mathrm{a}}$ is a factor expressing the rate of water entry at the anode side of the membrane and is proportional to the current density; $\kappa_{\mathrm{a}}$ is a factor characterizing the concentrationgradient-driven water flux into or out of the membrane; $C_{\mathrm{a}}$ is the concentration of water at the anode-membrane interface; $C_{\mathrm{H}_{2} \mathrm{O}}(0)$ is the water concentration in the membrane at $x=0$.

\subsubsection{Concentration conditions at membrane-cathode interface}

Two types of boundary condition for the water concentration at the membrane-cathode interface are studied. One is the constant water concentration:

$C_{\mathrm{H}_{2} \mathrm{O}}(d)=C_{0}$

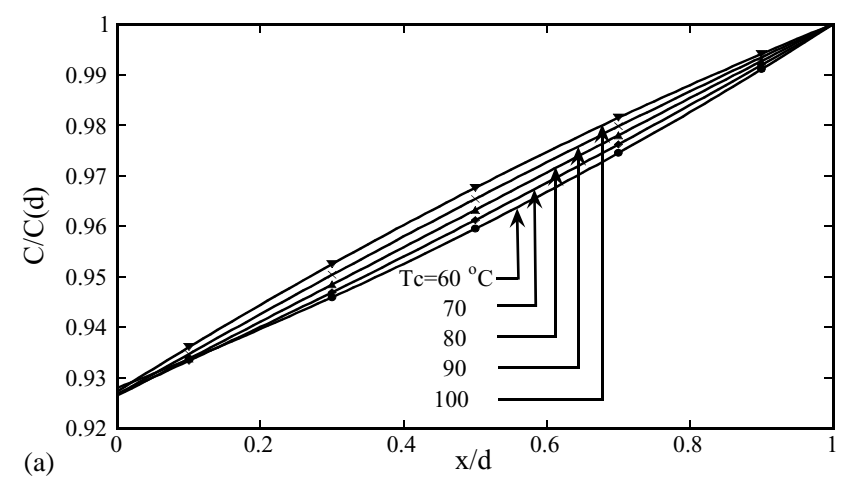

(b)
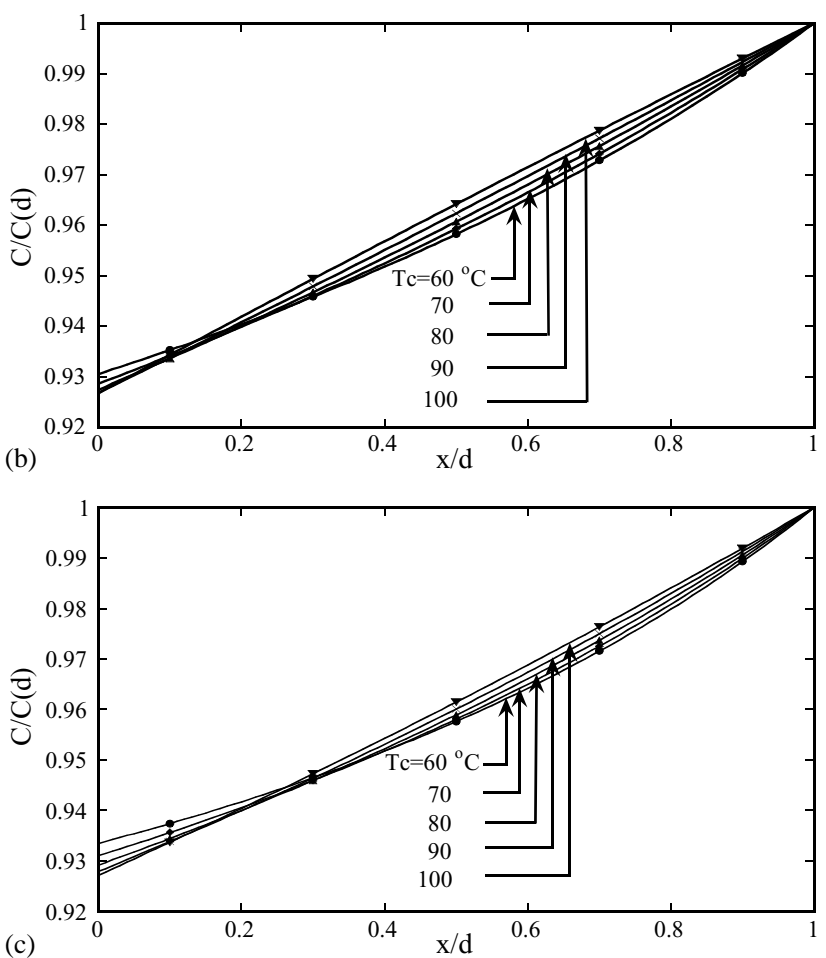

Fig. 5. Effect of $T_{\mathrm{c}}$ on water concentration distribution with $i=0.1 \mathrm{~A} \mathrm{~cm}^{-2}$ and water-flux condition at cathode side: (a) $T_{\mathrm{a}}=60^{\circ} \mathrm{C}$; (b) $T_{\mathrm{a}}=80^{\circ} \mathrm{C}$; (c) $T_{\mathrm{a}}=100^{\circ} \mathrm{C}$. 
the other is a water-flux condition:

$$
\begin{aligned}
\frac{\nu_{\mathrm{c}} i}{F} & +\kappa_{\mathrm{c}}\left[C_{\mathrm{c}}-C_{\mathrm{H}_{2} \mathrm{O}}(d)\right] \\
= & D_{\mathrm{c}}^{(0)} \frac{\partial C_{\mathrm{H}_{2} \mathrm{O}}(d)}{\partial x}-\frac{i}{F}\left[w_{\mathrm{c}}^{(0)}+w_{\mathrm{c}}^{(1)} C_{\mathrm{H}_{2} \mathrm{O}}(d)\right]
\end{aligned}
$$

where $v_{\mathrm{c}}$ is a factor expressing the rate of water entry at cathode side of the membrane proportional to the current density; $C_{\mathrm{H}_{2} \mathrm{O}}(d)$ is the water concentration at $x=d$ in Eq. (16); $D_{\mathrm{c}}^{(0)}$ is the diffusion coefficient of water at cathode side of the membrane.

\subsubsection{Thermal conditions at anode and cathode sides}

In this study, the thermal conditions at the anode and cathode sides of the membrane are constant temperatures,
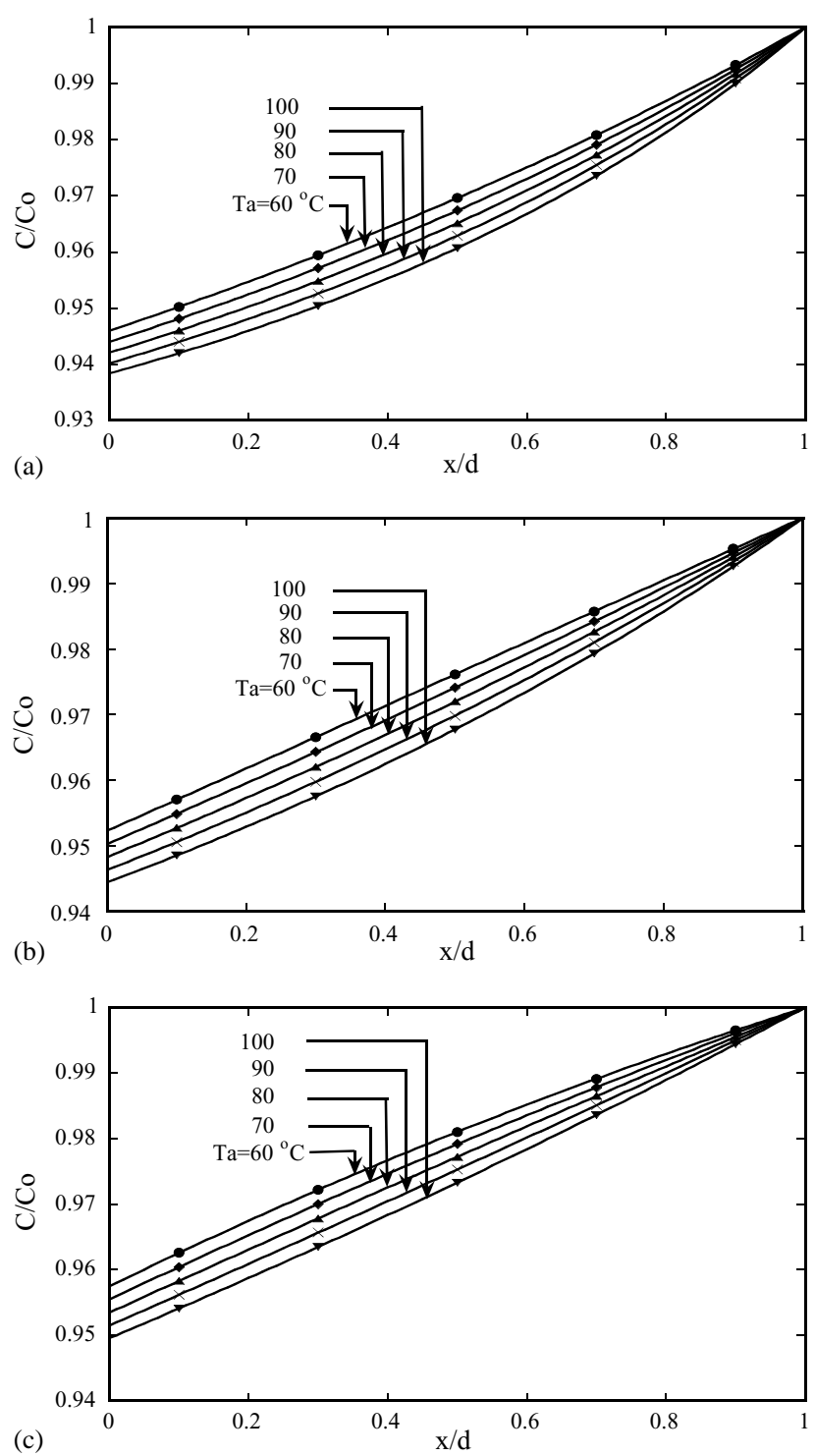

Fig. 6. Effect of $T_{\mathrm{a}}$ on water concentration distributions with $i=0.1 \mathrm{~A} \mathrm{~cm}^{-2}$ and constant cathode concentration $C_{\mathrm{c}}=1.59 \times 10^{-4}$ mol cm ${ }^{-3}$ : (a) $T_{\mathrm{c}}=60^{\circ} \mathrm{C}$; (b) $T_{\mathrm{c}}=80^{\circ} \mathrm{C}$; (c) $T_{\mathrm{c}}=100^{\circ} \mathrm{C}$.
$T_{\mathrm{a}}$ and $T_{\mathrm{c}}$, respectively, i.e.,

$$
\begin{aligned}
& T(0)=T_{\mathrm{a}} \\
& T(d)=T_{\mathrm{c}}
\end{aligned}
$$

\section{Numerical method}

The system of the governing equations mentioned above is non-linear and is difficult to obtain an analytical solution. In this work, the control volume finite difference method is adopted to solve the non-linear, coupled ordinary differential equations. The detailed solution scheme has been published elsewhere [19]. To check the grid independence, solutions on various grid systems are examined. In the separate numerical runs, it is found that there are no differences among the
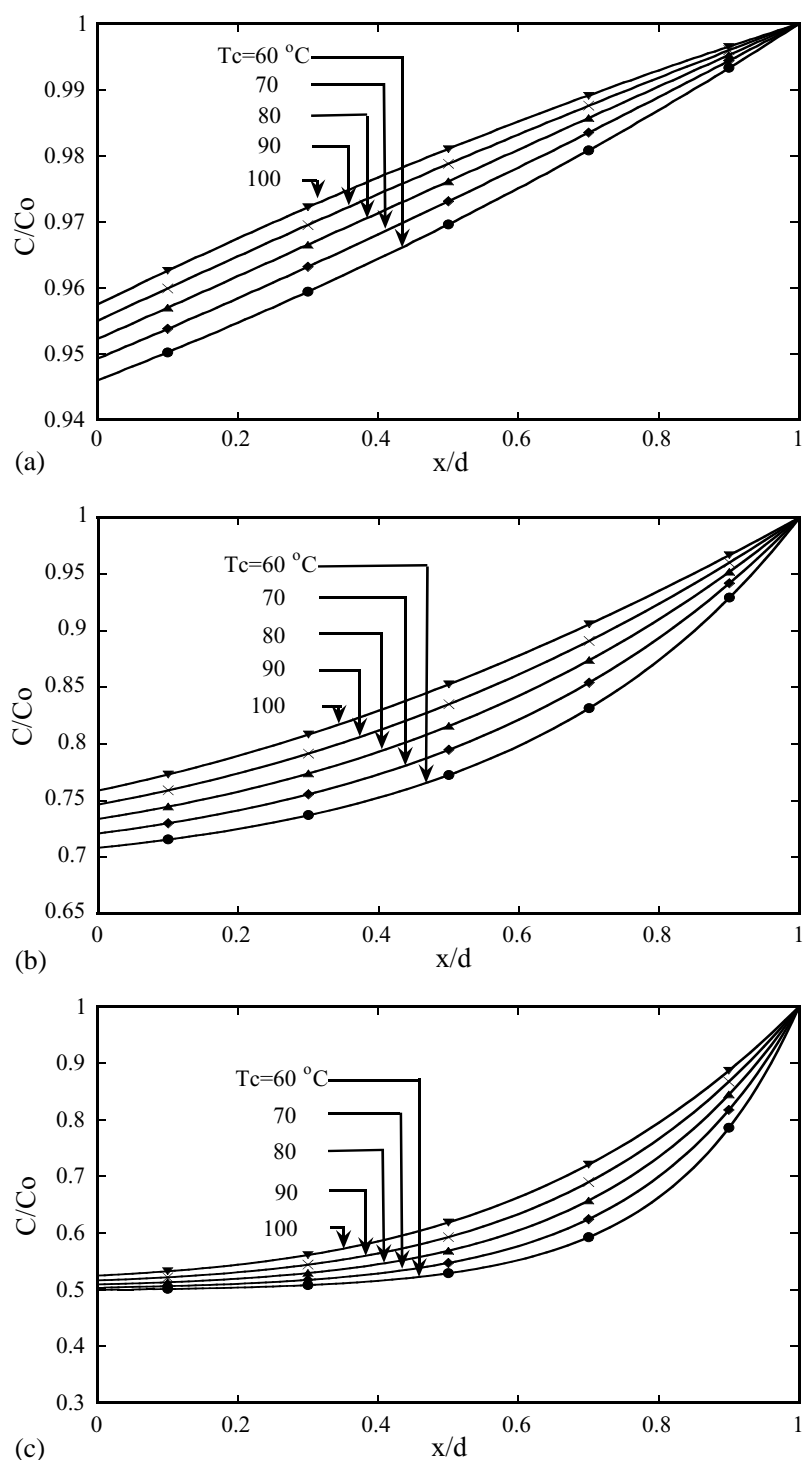

Fig. 7. Effect of $T_{\mathrm{c}}$ on water concentration distribution with $T_{\mathrm{a}}=60^{\circ} \mathrm{C}$ and constant cathode concentration $C_{\mathrm{c}}=1.59 \times 10^{-4} \mathrm{~mol} \mathrm{~cm}^{-3}$ : (a) $i=0.1 \mathrm{~A} \mathrm{~cm}^{-2}$; (b) $i=0.5 \mathrm{~A} \mathrm{~cm}^{-2}$; (c) $i=1.1 \mathrm{~A} \mathrm{~cm}^{-2}$. 
solutions with three grid arrangements of 1000, 2000 and 3000 points. In order minimize the calculating time, 1000 grids are adopted for the present problem. Additionally, it is important to compare the predicted results with existing numerical or experimental data. In the comparison shown in Fig. 2, it is apparent that the present predictions agree well with those of Okada et al. [9]. Through these preliminary tests, it is found that the numerical method is suitable for the present study.

\section{Results and discussion}

In Section 2, several parameters appear in the formulation. The physical parameters and their corresponding values are presented in Table 1. To disclose the effects of
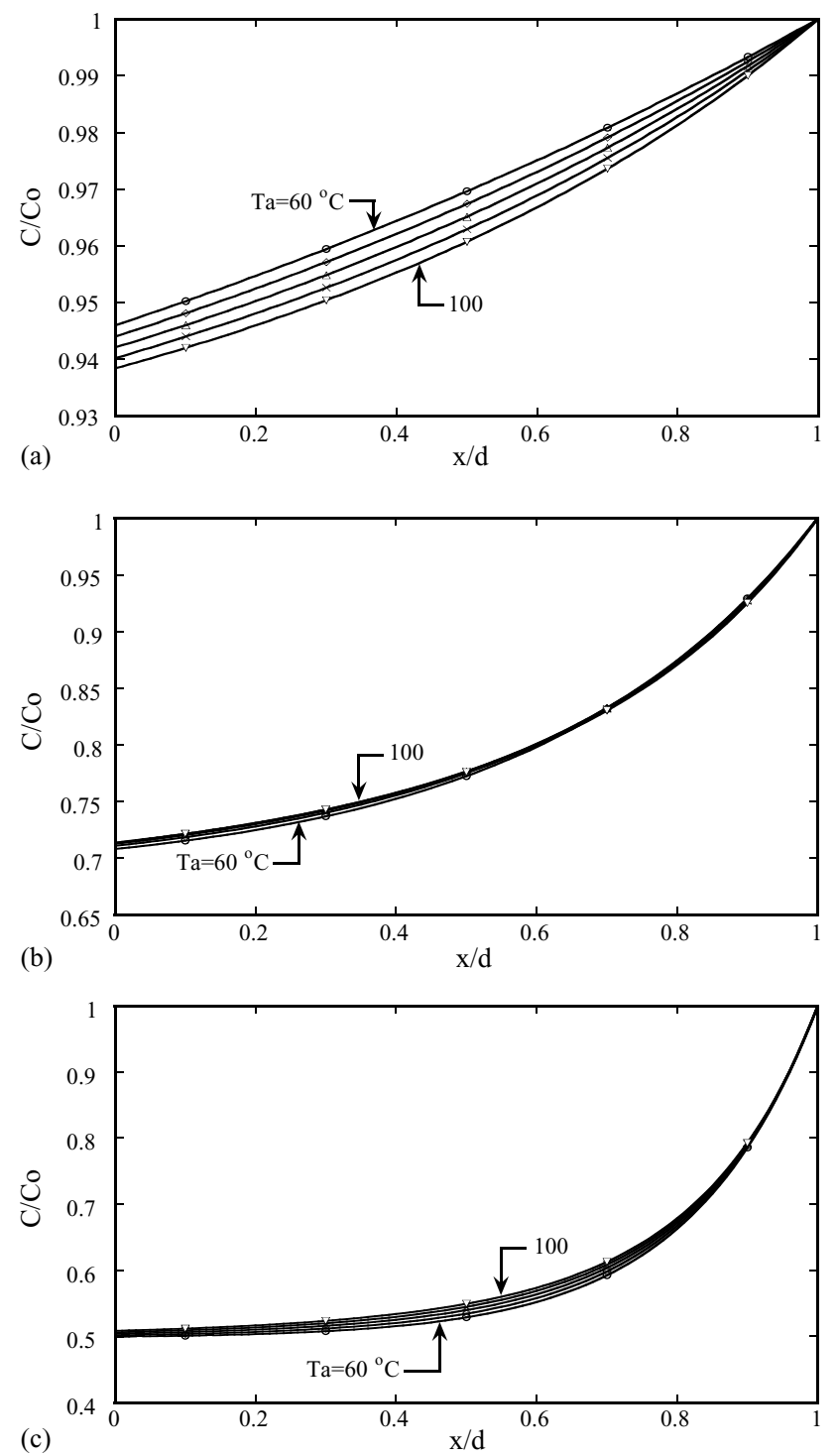

Fig. 8. Effect of $T_{\mathrm{a}}$ on water concentration distribution with $T_{\mathrm{c}}=60^{\circ} \mathrm{C}$ and constant cathode concentration $C_{\mathrm{c}}=1.59 \times 10^{4} \mathrm{~mol} \mathrm{~cm}^{-3}$ : (a) $i=0.1 \mathrm{~A} \mathrm{~cm}^{-2}$; (b) $i=0.5 \mathrm{~A} \mathrm{~cm}^{-2}$; (c) $i=1.1 \mathrm{~A} \mathrm{~cm}^{-2}$. the temperature-dependent diffusion coefficient on the water concentration distribution, Fig. 3(a) and (b) shows, respectively, the distribution of water concentration with or without consideration of a variable diffusion coefficient. It is seen that the water concentration increases with $x / d$. In addition, a large water concentration is noted for a system with a lower anode temperature $T_{\mathrm{a}}$. It is also found that these are noticeable differences between the results with or without consideration of variable diffusion coefficient. This implies that the effects of a variable diffusion coefficient on the water content in the membrane are of importance.

For thermal and water management in PEMFCs, the thermal effects of the anode and cathode temperatures $\left(T_{\mathrm{a}}\right.$ and $T_{\mathrm{c}}$ ) on the water concentration in the membrane may be important. The effects of $T_{\mathrm{a}}$ and $T_{\mathrm{c}}$ on the water concentration at a current density $i=0.1 \mathrm{~A} \mathrm{~cm}^{-2}$ and a water concen-
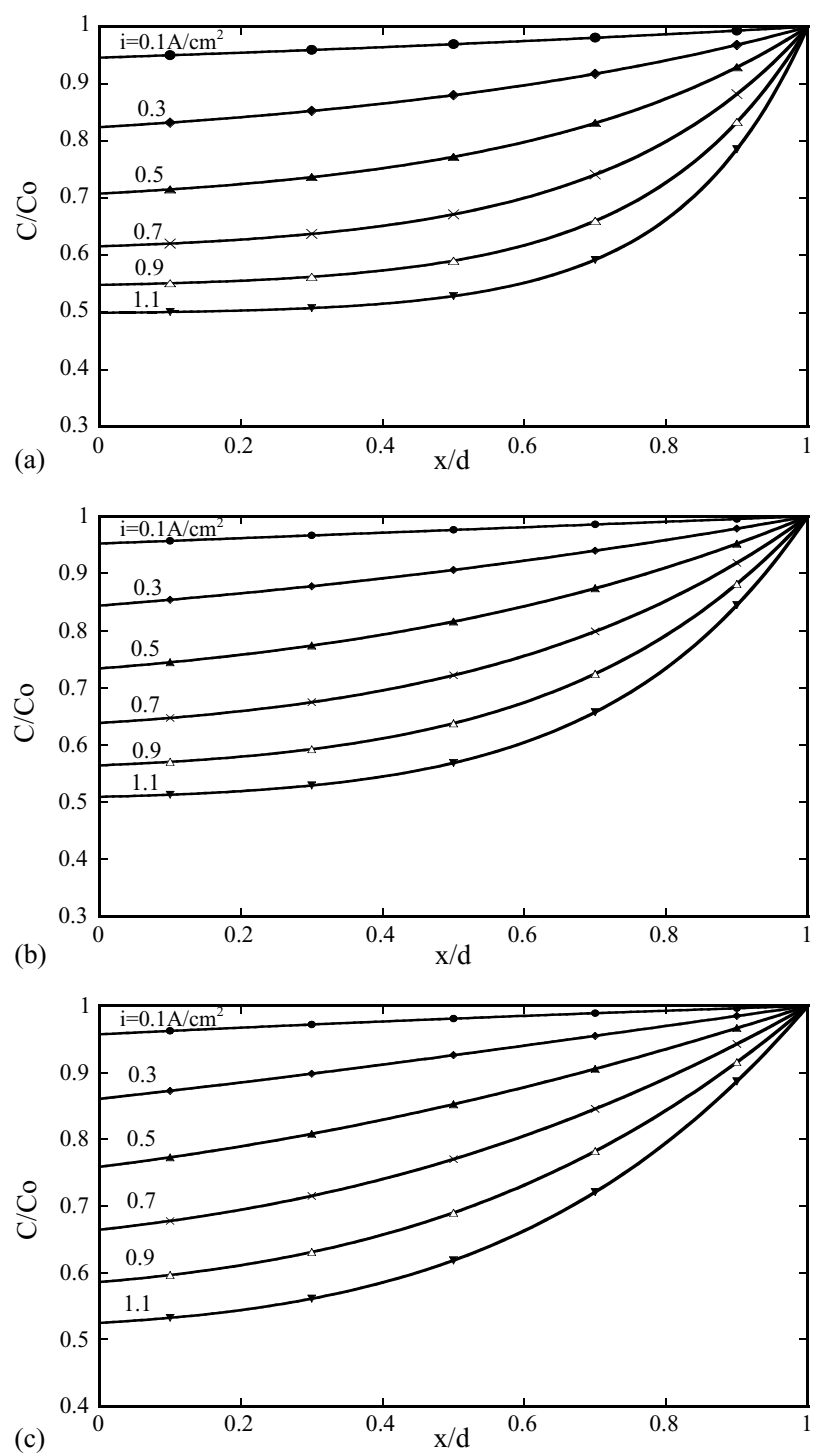

Fig. 9. Effect of current density $i$ on water concentration distribution with $T_{\mathrm{a}}=60^{\circ} \mathrm{C}$ and constant cathode concentration $C_{\mathrm{c}}=1.59 \times 10^{4} \mathrm{~mol} \mathrm{~cm}^{-3}$ : (a) $T_{\mathrm{c}}=60^{\circ} \mathrm{C}$; (b) $T_{\mathrm{c}}=80^{\circ} \mathrm{C}$; (c) $T_{\mathrm{c}}=100^{\circ} \mathrm{C}$. 
tration on cathode side of $C_{\mathrm{c}}=1.59 \times 10^{-4} \mathrm{~mol} \mathrm{~cm}^{-3}$ are shown in Fig. 4. That data show that the water concentration at the anode side of the membrane decreases with increase in $T_{\mathrm{a}}$. This can be explained by the fact that, as $T_{\mathrm{a}}$ is increased, the diffusion coefficient becomes larger (see Eq. (8a)). Therefore, water diffusion from the anode side of the membrane is enhanced. This means that an increase in $T_{\mathrm{a}}$ causes dehydration of the anode. At a fixed $T_{\mathrm{a}}$, a higher water concentration within the membrane can be found in a system with a higher cathode temperature $T_{\mathrm{c}}$ due to strong back-diffusion from the cathode to the anode.

The effects of cathode temperature on the water concentration distribution with water-flux conditions are shown in Fig. 5. As in Fig. 4, three sub-plots with different anode temperatures $T_{\mathrm{a}}$ are presented. It is noteworthy that the dimensionless water concentration, $C / C(d)$, is presented, where

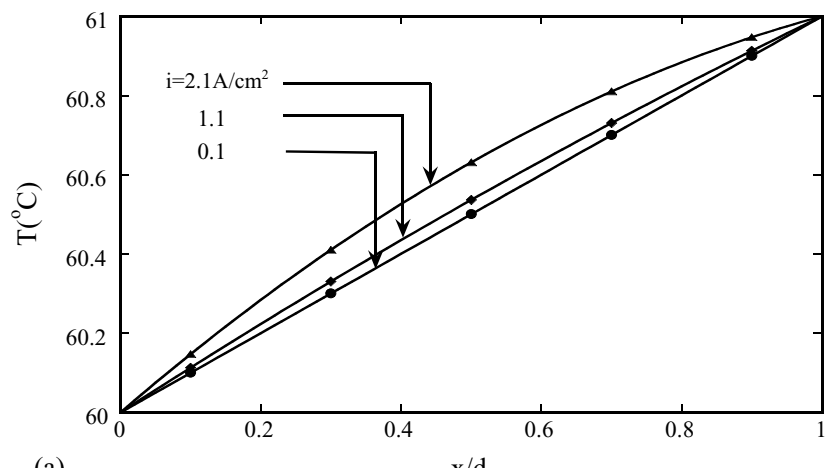

(a)
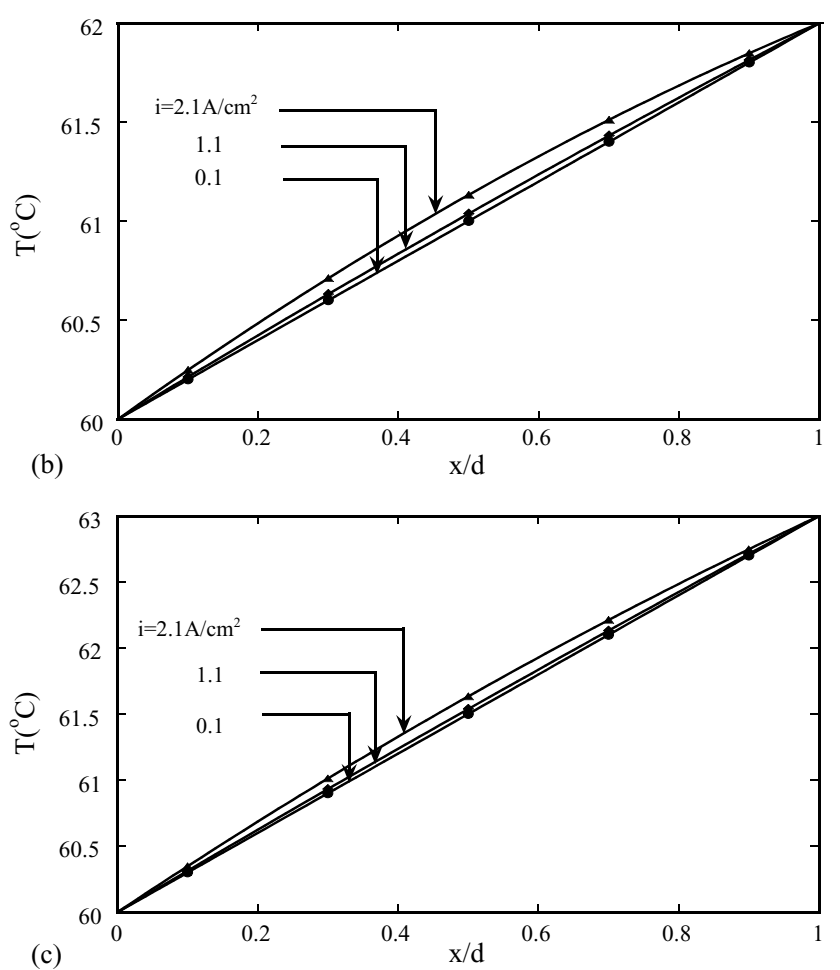

Fig. 10. Effect of current density $i$ on temperature distribution with $T_{\mathrm{a}}=60^{\circ} \mathrm{C}$, constant cathode concentration $C_{\mathrm{c}}=1.59 \times 10^{4} \mathrm{~mol} \mathrm{~cm}^{-3}$ : (a) $T_{\mathrm{c}}=61^{\circ} \mathrm{C}$; (b) $T_{\mathrm{c}}=62{ }^{\circ} \mathrm{C}$; (c) $T_{\mathrm{c}}=63{ }^{\circ} \mathrm{C}$.
$C(d)$ is the water concentration at the cathode side of the membrane. An overall inspection in Fig. 5 indicates that, for water-flux conditions at the cathode side, the water concentration increases with the normalized depth from the anode side. In the region near the anode side (i.e., at small values of $x / d$ ), a larger normalized water concentration, $C / C(d)$, is noted for a system with a lower $T_{\mathrm{c}}$. By contrast, in the region away from the anode side (i.e., at large values of $x / d), C / C(d)$ increases with an increase in $T_{\mathrm{c}}$. In fact, the local water concentration, $C(x)$, is a function of the operating temperatures, $T_{\mathrm{c}}$ and $T_{\mathrm{a}}$. As $T_{\mathrm{c}}$ is raised, membrane dehydration occurs at the anode side, but hydration occurs at the cathode side.

The dependence of the water concentration profiles on the temperature at cathode side of the membrane $\left(T_{\mathrm{c}}=60\right.$ to $100^{\circ} \mathrm{C}$ ) is shown in Fig. 6. Here the water concentration at the cathode side of the membrane is kept constant. The results show that at fixed $T_{\mathrm{a}}$ a higher water concentration at the anode side of the membrane is found in a system with a higher $T_{\mathrm{c}}$. This is due to the fact that increasing $T_{\mathrm{c}}$ will markedly enhance the membrane hydration. That is, the back diffusion of water to the anode side is significant at a high $T_{\mathrm{c}}$.

In order to realize how the current density affects the water content in the membrane, Fig. 7 presents the effects of

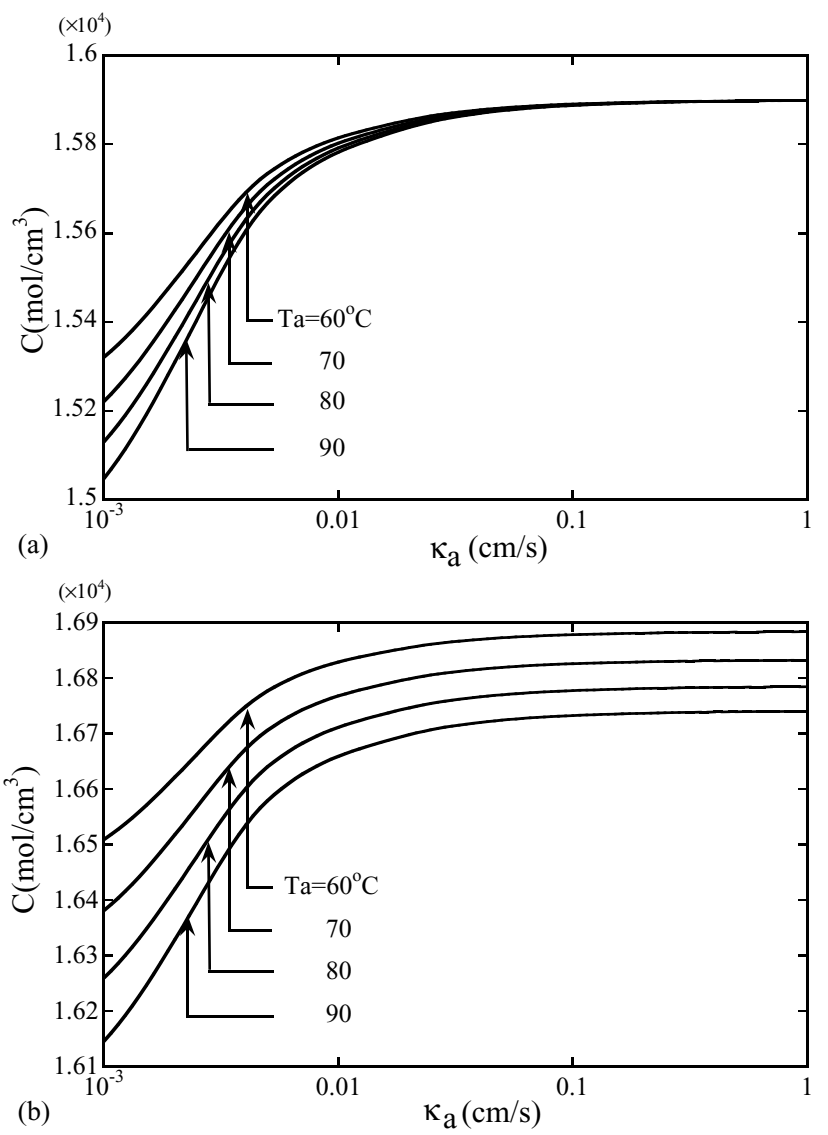

Fig. 11. Effect of humidification factor $\kappa_{\mathrm{a}}$ on water concentration distribution with $T_{\mathrm{a}}=60^{\circ} \mathrm{C}, i=0.1 \mathrm{~A} \mathrm{~cm}^{-2}$ and water-flux condition at cathode side under $T_{\mathrm{c}}$ : (a) concentration at anode side; (b) concentration at cathode side. 
the current density $i$ on the water concentration distribution with $T_{\mathrm{a}}=60^{\circ} \mathrm{C}$ and a constant cathode concentration of $C_{\mathrm{c}}=1.59 \times 10^{4} \mathrm{~mol} \mathrm{~cm}^{-3}$. The influence of $i$ on water concentration at the anode side is similar for different $T_{\mathrm{c}}$. Careful inspection of the data shows that there is a smaller water concentration at the anode side at a large current density. This can be explained by noting that an increase in current density causes the membrane to be seriously dehydrated due to water drag by electro-osmosis. As for the results mentioned above, at a fixed $x / d$ and $i$, the water concentration increases with an increase in $T_{\mathrm{c}}$.

The effect of $T_{\mathrm{a}}$ on the water concentration distribution is shown in Fig. 8 with $T_{\mathrm{a}}=60^{\circ} \mathrm{C}$ and $C_{\mathrm{c}}=1.59 \times$ $10^{4} \mathrm{~mol} \mathrm{~cm}^{-3}$ under different $i$. The water concentration profile has a parabolic form. As the current density is increased, however, the deviation in the water concentration distribution at different $T_{\mathrm{a}}$ becomes small. Therefore, the temperature at the anode side, $T_{\mathrm{a}}$ has only a small impact on the water concentration in the membrane at high current density.

The influence of current density $i$ on the water concentration distributions at different anode operating temperatures are presented in Fig. 9. By comparing the results in Fig. 9(a), it is found that the anode side of the membrane tends to become dehydrated as the current density is raised. This is because that the electro-osmotic drag effect becomes stronger as the current density is higher. It is also found in the separate numerical runs that the membrane is much wetter for the system with a higher $T_{\mathrm{c}}$ than that with a lower $T_{\mathrm{c}}$. This is due to the temperature-dependence of the diffusion coefficient.

The relationship between the current density and the temperature distribution is shown in Fig. 10. It is clearly shown in Fig. 10(a) that when the current density is raised, the temperature changes sharply at the anode side of membrane. For example, when it is necessary to speed up a car, the current density must go up. This will cause dehydration of the membrane, which, in turns, causes the temperature to increase and become more non-uniform. Thermal expansion of the membrane may become serious and lead to the breakdown of the membrane. Therefore, the strength of the membrane is a key factor for fuel cells operating under high current density conditions.

The effect of the humidification parameter $\kappa_{\mathrm{a}}$ on the water concentration at the anode and cathode sides with $T_{\mathrm{a}}=$ $60{ }^{\circ} \mathrm{C}$ and $i=0.1 \mathrm{~A} \mathrm{~cm}^{-2}$ are shown in Fig. 11. When $\kappa_{\mathrm{a}}$ is increased, water vapour enters the membrane more freely from the anode gas-diffusion electrode through the anode-membrane interface which, in turn, results in an increase in the water content. A careful inspection of Fig. 11 indicates that the water concentration changes sharply when $\kappa_{\mathrm{a}}$ is increased from $10^{-3}$ to $10^{-1} \mathrm{~cm} \mathrm{~s}^{-1}$. But, for $\kappa_{\mathrm{a}}>$ $10^{-1}$, the effect of $\kappa_{\mathrm{a}}$ on the water content in the membrane is insignificant.

The influence of the parameters of the electro-osmotic drag at anode side $\left(v_{\mathrm{a}}\right)$ on the water concentration at the anode and cathode sides is presented in Fig. 12. It is observed that the water concentration increases linearly with increase
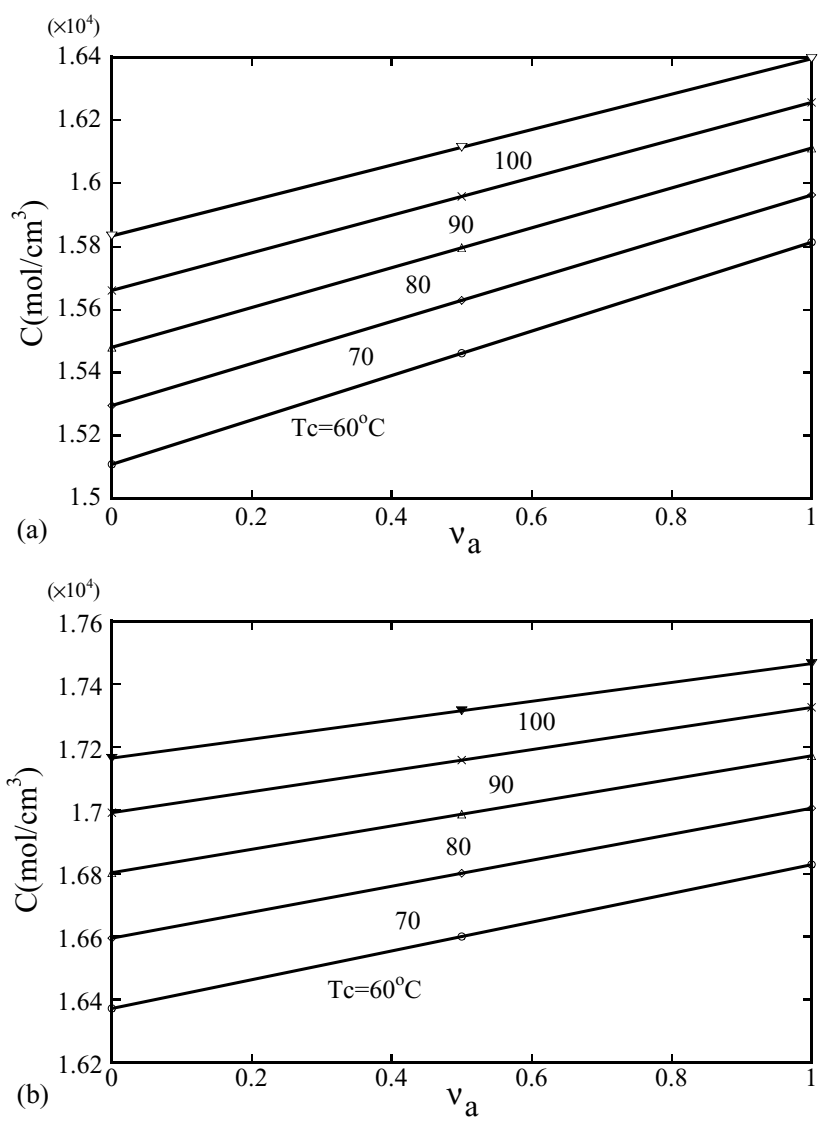

Fig. 12. Effect of humidification factor $v_{\mathrm{a}}$ on water concentration distribution with $T_{\mathrm{a}}=60^{\circ} \mathrm{C}, i=0.1 \mathrm{~A} \mathrm{~cm}^{-2}$ and water flux at cathode side under different $T_{\mathrm{c}}$ : (a) concentration at anode side; (b) concentration at cathode side.

in $v_{\mathrm{a}}$. When $v_{\mathrm{a}}$ is increased, the water enters easily the membrane from the anode gas-diffusion electrode through the anode-membrane interface and thus results in an increase in the water content within the membrane.

\section{Conclusions}

A detailed analysis of the thermal and water management in the PEMFC membrane with coupling effects of mass diffusion and temperature gradient have been performed by using a one-dimensional mathematical model. The thermal-mass diffusion coupling effects are taken into account with consideration of the temperature-dependent diffusivity. The model can predict the water distribution in the membrane under different operating conditions. This is useful for selecting the optimal membrane material and estimating the gas-inlet temperature or working density in designing a PEMFC. The major findings in this study are summarized as follows.

(i) Increasing the temperature at the anode side of the membrane can cause dehydration of the membrane. 
(ii) Increasing the current density will increase dehydration of the anode side of the membrane. This is attributed to the strong electro-osmotic drag effect under the operating conditions of high current density.

(iii) At high current density, the temperature effect on the water concentration becomes smaller. The current density effect dominates the water concentration distribution.

(iv) Temperature distribution changes sharply in the membrane at high current densities. This can damage the membrane.

(v) Increasing the humidification factor $\kappa_{\mathrm{a}}$ augments the water concentration at both the anode and the cathode sides of the membrane. Never the less, increase in $\kappa_{\mathrm{a}}$ above $10^{-1} \mathrm{~cm} \mathrm{~s}^{-1}$ has little influence on the water concentration.

(vi) At fixed current density, the effects of the parameters of electro-osmotic drag, $v$, on the water concentration is considerable. The dependence of the water content on $v$ is almost linear.

\section{Acknowledgements}

The authors are grateful for financial support from the National Science Council of Taiwan, NSC 92-2212-E-21 1-001 and NSC 92-2623-7-002-006-ET.

\section{References}

[1] D.M. Bernardi, J. Electrochem. Soc. 137 (11) (1990) 3344 3350.

[2] T.E. Springer, T.A. Zawodizinski, S. Gottesfeld, J. Electrochem. Soc. 138 (8) (1991) 2334-2342.

[3] T.F. Fuller, J. Newman, J. Electrochem. Soc. 139 (5) (1992) 1332 1337.

[4] T.V. Nguyen, R.E. white, J. Electrochem. Soc. 140 (8) (1993) 2178 2186.

[5] T.F. Fuller, J. Newman, J. Electrochem. Soc. 140 (5) (1993) 1218 1225.

[6] R. Mosdale, S. Srinivasan, Electrochimi. Acta 40 (4) (1995) 413 421.

[7] H.H. Voss, D.P. Wilkimson, P.G. Pickup, M.C. Johnson, V. Basura, Electrochim. Acta 40 (3) (1995) 321-328.

[8] G. Xie, T. Okada, J. Electrochem. Soc. 142 (9) (1995) 3057-3062.

[9] T. Okada, G. Xie, Y. Tanabe, J. Electroanal. Chem. 413 (1996) 4965.

[10] T. Okada, G. Xie, M. Meeg, Electrochim. Acta 43 (1998) 2141-2155.

[11] T. Okada, J. Electroanal. Chem. 465 (1999) 1-17.

[12] T. Okada, J. Electroanal. Chem. 465 (1999) 18-29.

[13] P. Argyropoulos, K. Scott, W.M. Taama, J. Power Sources 79 (1999) 169-183.

[14] P. Argyropoulos, K. Scott, W.M. Taama, J. Power Sources 79 (1999) 184-198.

[15] S. Motupally, A.J. Becker, J.W. Weidner, Electrochem. Soc. 147 (9) (2000) 3171-3177.

[16] J.J. Baschuk, X. Li, J. Power Sources 86 (2000) 181-196.

[17] A. Rowe, X. Li, J. Power Sources 102 (2001) 82-96.

[18] N. Djilali, D. Lu, Int. J. Therm. Sci. 41 (2002) 29-40.

[19] S.L. Lee, Int. J. Heat Mass Transfer 32 (1989) 2065-2073. 